\title{
Peaceful Families: American Muslim Efforts Against Domestic Violence
}

PRINCETON: PRINCETON UNIVERSITY PRESS, 2019. 392 PP.

\section{JULIANE HAMMER}

The Ohio suburb where I live prides itself on being safe. This claim mainly rings true, except for the two women in our community who were murdered by their husbands in the past two years. Juliane Hammer's Peaceful Families: American Muslim Efforts Against Domestic Violence challenges readers to confront this pervasive and insidious form of violence. Based on extensive participant-observation, interviews with advocates, and analysis of media and other literature, Hammer explores the multi-faceted efforts of domestic violence (DV) advocates to eradicate domestic violence within Muslim communities and to provide care and support for survivors.

This book review began unconventionally, an approach that reflects Hammer's urgent challenge to scholars that they abandon the academic pretense of critical distance when writing about enduring social problems. Hammer's motivation in writing Peaceful Families is to "stop the violence" (1-2). This goal, alongside Hammer's feminist commitment to gender justice, means that she strives to "strike a balance between analysis, which often contains direct or indirect critique" and trying to "honor the work of Muslim 
DV advocates" (23). These feminist commitments sometimes sit in tension with the approaches of DV advocates and religious authorities such as imams. Hammer adopts a highly reflexive approach, acknowledging when she refuses analytical moves such as deconstruction and other forms of critique in favor of prioritizing the voices of survivors and advocates. She also assiduously protects the identities of her interlocutors through composite ethnographic portraits that demonstrate the extent of the trauma that survivors endure and the many challenges that advocates face in trying to help them. In addition to recognizing the crucial work that advocates accomplish, Peaceful Families is an evocative feminist reflection on academic ethics and the responsibilities that scholars have to the communities upon which they rely to do their work.

What follows from this approach is a revealing portrait of the vital work of Muslim DV advocates and organizations. From the outset, Hammer notes that the landscape of DV advocacy among American Muslims, like the DV movement in the US more broadly, is internally diverse and is in constant flux due to funding scarcity, advocate burnout, and state intervention. Whatever their organizational location, however, DV advocates share an "ethic of non-abuse," an embodied practice that undergirds how they navigate tensions around textual interpretation, religious authority, and gendered norms in American Muslim communities (2). This ethic of non-abuse is primary; advocates then turn to texts such as the Qur'an for religious support and to help in their efforts to mobilize Muslim communities. At the same time, advocates work to end violence and support survivors in relation to the mainstream DV movement as well as broader American cultural discourses that posit Muslims as uniquely inclined toward familial violence. She uses the concept of "protective patriarchy" to describe the family model that advocates use as a "strategic tool" and "ideological middle ground" to mobilize Muslim communities around issues of family that are of perennial concern (16). This strategy is crucial to allay the suspicions within Muslim communities that advocates are aiming to dismantle traditional Muslim family structures. 
As members of a highly surveilled group, American Muslim DV advocates confront domestic violence in a political atmosphere fraught with "anti-Muslim hostility" (38). The first chapter begins with the ambivalent effects of the media storm surrounding the horrific murder of Aasiya Zubayr in 2009. On the one hand, Hammer shows how the killing raised the visibility of the issue of domestic violence among American Muslims. On the other, the incident, among others, subjected Muslims to racialized tropes and suspicion about their purported propensity toward "honor killings." This degree of scrutiny has the effect of further silencing survivors, hindering Muslim communities from recognizing the issue, and constraining the already limited choices that advocates have as they seek to end violence (54).

Despite a political, religious, and media environment that facilitates the silencing of survivors, Peaceful Families shows that a loosely-connected network of advocates are raising awareness of abuse, centering survivor voices, and honoring the memory of those Muslim women who do not survive their abuse, through wide-ranging educational initiatives as well as direct services for survivors (Chapter 6). Hammer gives ample space to the stories of survivors and their advocates who seek to provide support in a Muslim way. These evocative portraits reveal the insidious nature of domestic abuse, its enduring effects, and the many structural impediments to recognizing, preventing, and stopping it. Drawing on feminist critique of work, Hammer emphasizes the multivalent, often invisible forms of labor that advocates undertake with minimal resources and often in tension with concurrent state programs and initiatives.

Chapters 3 and 4 focus on how DV advocates use Islamic texts and concepts to build awareness through education among American Muslims and implementing possible solutions. While their own ethic of non-abuse is not necessarily rooted in Islamic texts or ethics, the advocates recognize that emplacing their work within an Islamic framework is essential. As result, their trainings, print materials, and fundraising approaches all invoke Islam as a resource in ending domestic violence, as well as an impediment 
(54). In this, American Muslim DV advocates differ from many mainstream DV organizations that often view religious traditions as obstacles to ending domestic abuse (54). By contrast, Muslim DV advocates emphasize the family as the "building blocks for Muslim communities" and emphasize the care of children in addition to serving the needs of individual survivors (54). In trainings and other educational events hosted in mosques, homes, and community centers, DV advocates use the idea of a "cohesive and historically anchored Islamic tradition" to repudiate any suggestion that domestic violence is permissible for Muslims (73). In the process, DV advocates claim the authority to interpret Muslim sacred texts, even as those claims are often challenged by or mediated through male Muslim religious authorities who often provide guidance to survivors and frequently subordinate concern for survivors to the health of Muslim families.

Toward the end of the book (Chapter 7), Hammer considers the relationship of Muslim DV initiatives to interfaith programs and the state. Hammer notes that she is hesitant to take space away from the central subjects of her study in favor of exploring broader structures and social developments. Yet in the course of reading this chapter, I wanted to know more about the ethic of non-abuse and whether and how it is connected to the moral commitments of other DV advocates. While I appreciate Hammer's refusal to deconstruct the theological and ethical positions of advocates when telling their stories, the fact that advocates do not foreground their faith as the basis for their ethic of non-abuse suggests a more complicated set of ethical foundations that could have been fleshed out. Religion is often assumed to be the primary form of identity and ethical framework for Muslims, but Hammer's account raises the possibility of a more complicated trajectory.

Peaceful Families provides an accessible, fine-grained analysis of the tireless local efforts of advocates working within Muslim communities to end domestic violence. Yet the book's implications are anything but local. It challenges scholars to reflect on our own actions when confronted with abuse, not just in universities 
where abuse is also endemic, but also in the other communities to which we contribute. Peaceful Families further invites us to ask why certain endemic problems spur us to action, while others do not. Joining a growing number of studies that investigate the religious contexts of abuse, this book is a model for academic writing about survivors and exposing the limits of our academic repertoire in seeking to render abuse visible and intelligible.

Justine Howe

Associate Professor, Department of Religious Studies Case Western Reserve University, Cleveland, OH

doi: 10.35632/ajis.v38i1-2.2970 